\title{
Recent Developments on the Synthetic and Biological Applications of Chalcones-A Review
}

\author{
Vagish Channa Basappa ${ }^{1(\mathbb{D})}$, Sowmya Ramaiah ${ }^{2}{ }^{(\mathbb{D})}$, Sudeep Penubolu ${ }^{1(\mathbb{C})}$, Ajay Kumar Kariyappa ${ }^{1, *(\mathbb{D})}$ \\ 1 Department of Chemistry, Yuvaraja College, University of Mysore, Mysuru, India \\ 2 Department of Botany, Yuvaraja College, University of Mysore, Mysuru, India \\ * Correspondence: ajaykumar@ycm.uni-mysore.ac.in (A.K.K.);
}

Scopus Author ID 6506781846

Received: 3.03.2021; Revised: 2.04.2021; Accepted: 6.04.2021; Published: 19.04.2021

\begin{abstract}
Chalcones are precursors of the biosynthesis of flavonoids present in plants. These motifs serve a wide range of applications, from synthetic to pharmacological to physical spheres. Chalcone derivatives attracted the scientific community all over the world in recent times due to their diversified applications. The presence of reactive $\alpha, \beta$-unsaturated carbonyl moiety in chalcones makes them a versatile intermediate in synthesizing various classes of compounds of biological and physical interest. More importantly, the chalcones themselves have been known to possess enormous biological activities and physical properties like semiconductor, non-linear optical, fluorescence, and electronic properties. In this context, the present review summarises the overall developments in the synthetic, pharmacological, and physical applications of chalcones in recent fast. The critical discussion was attempted on the synthetic applications and biological potencies as anti-cancer, antidiabetic, antimicrobial, antioxidant, and anti-inflammatory.
\end{abstract}

Keywords: antibacterial; annulation; anticancer; antidiabetic; antifungal; anti-inflammatory.

(C) 2021 by the authors. This article is an open-access article distributed under the terms and conditions of the Creative Commons Attribution (CC BY) license (https://creativecommons.org/licenses/by/4.0/).

\section{Introduction}

Chalcones are 1, 3-diphenyl-2-propen-1-ones consist of a three-carbon $\alpha, \beta$-unsaturated carbonyl system, which exhibit a broad spectrum of biological activities. The natural and synthetic chalcones exhibit various pharmacological activities such as anti-inflammatory, antitumor, antibacterial, antifungal, antimalarial, antidiabetic, anti-cancer and antituberculosis. The promising activities, ease of synthesis, and simple and reactive chemical structure have significantly attracted chalcones [1]. This review focuses on the developments in the synthetic procedures, their utility as scaffolds in the synthesis of bioactive compounds, biological activity potentials, and their ability to form useful metal complexes, also physical properties associated with chalcone derivatives in the recent past.

\section{Synthesis and Synthetic Applications}

Of the many methods, the Claisen-Schmidt condensation of aromatic aldehydes and aromatic ketones in acidic or basic conditions (Scheme 1) [2]. The $\mathrm{MnO}_{2}$ nanorods on graphene oxide act as excellent catalysts for chalcones synthesis via Claisen-Schmidt condensation. The catalyst showed recyclability up to six times without significant loss of activity [3]. A simple, expeditious, and greener synthetic approach for chalcone derivatives, involving $p$ toluenesulfonic acid as a solid phase organocatalyst, accelerates Claisen-Schmidt condensation 
under mild and solvent-free reaction conditions was developed (Scheme 1) [4]. The method has advantages with short periods, desired products, simple workup, and easy purification, etc. The fluoro-substituted tris-chalcone derivatives were synthesized from phloroglucinol and benzaldehyde in three steps (Scheme 1) [5]. The tris-chalcones have shown inhibition of hCA I and II isoenzymes, acetylcholinesterase, butyrylcholinesterase. The base-catalyzed ClaisenSchmidt condensation reaction between aromatic aldehydes and ketones in methanol produced corresponding chalcones in good yields [6-11].<smiles>CC=CC(=O)[Al]</smiles>

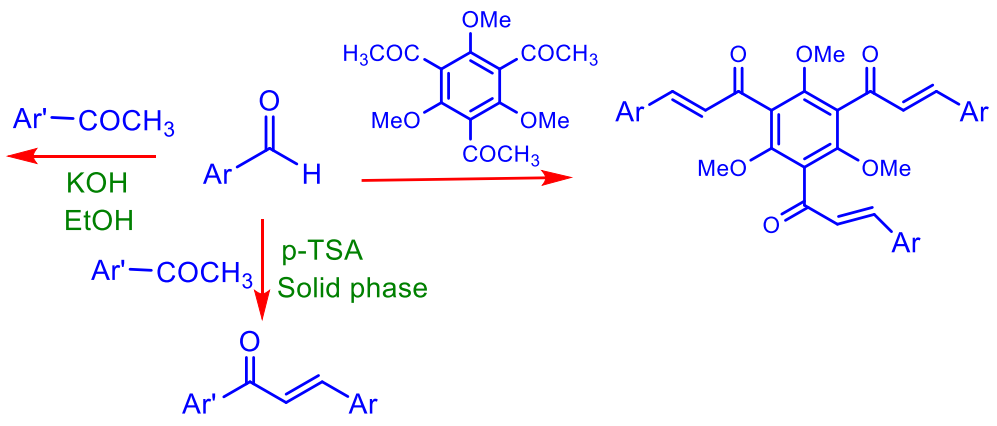

Scheme 1. Synthetic route for chalcones.

The bifunctional catalyst derived from a Cinchona alkaloid found it effective to perform the enantio- and diastereoselective Michael addition of $\alpha, \alpha$-dicyanoolefins chalcones in THF as solvent (Scheme 2) [12] to give the adducts in moderate yields, which exhibit antiplasmodial and cytotoxic activity. Chalcones have been efficiently transformed into pyrazoline carbothioamides [13] and pyrazoline carboxamides [14] through $(3+2)$ annulation reactions with thiosemicarbazide and semicarbazide, respectively. The base mediated convenient method for the synthesis of 3-acylpyrazoles and pyrazole-3-carboxylates was developed, which involves diazosulfone as 1,3-dipole and arylidenemalonates and arylidene1,3-dicarbonyls as dipolarophiles in cycloaddition reaction (Scheme 2) [15]. An environmentally benign method involving citrus extract medium was adopted to transform chalcones by their reaction with hydroxylamine into isoxazoles of antioxidant and antifungal potencies [16-18].

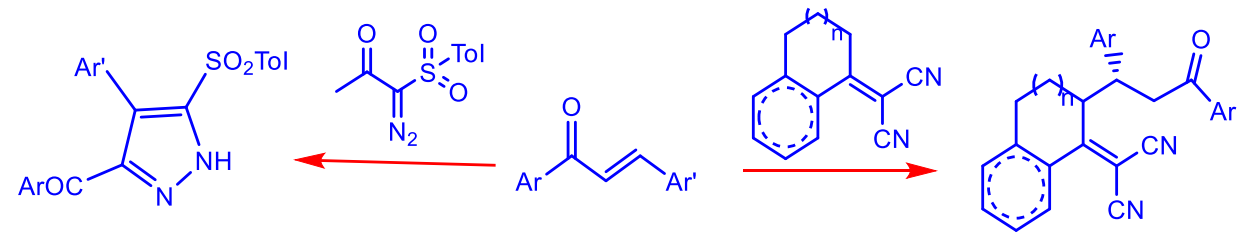

Scheme 2. Cycloaddition and coupling reactions of chalcones.

Indolizines were obtained through the one-pot cascade reaction between chalcone, pyridine, and benzyl bromide via [3+2] cycloaddition/oxidative aromatization promoted by $\mathrm{Cu}(\mathrm{OAc})_{2}$ in the presence of oxygen (Scheme 3) [19]. The method is convenient and does not require the isolation of intermediates.

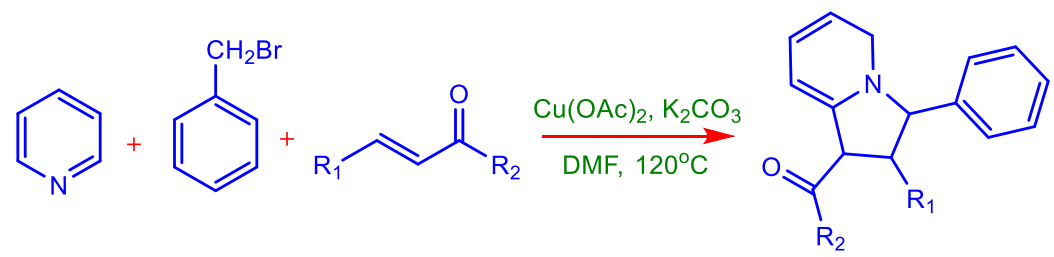

Scheme 3. Synthesis of fused pyrrolines from chalcones.

Palladium-catalyzed cross-coupling of ethyl acetohydroxamate with 4-bromo chalcones was developed to synthesize functionalized chalcones, wherein the ligand $t \mathrm{BuXPhos}$ 
found effective towards cross-coupling reaction to produce the product in good yields (Scheme 4) [20]. The hybridization approach followed by tandem cyclization into quinolinone derivatives and then by aldol condensation produces chalcone-sulfonamide compounds. The method controlled the sequential preparation of chalcone-sulfonamide hybrids [21]. Chalcones undergo highly regio- and stereoselective Diels-Alder cycloaddition with dienophiles to give $\mathrm{N}$-substituted exo-4,5,6,7-tetrahydrobenzoxazol-2-ones (Scheme 4) [22]. The endo/exo stereoselectivity is dependent on the solvent, polarity, and substituents. The chalcones have been efficiently transformed into isoxazolines [23] and pyrrolines [24] in good yields.

The intermolecular [2+2] photocycloaddition of chalcones with 2,3-dimethyl-1,3butadiene under visible-light irradiation forms cyclobutane derivatives (Scheme 4) [25]. Without using any photosensitizer, metal catalyst, and solvent, the reaction proceeded with high regio- and stereoselectivity. Mild reaction conditions and no additives make the reaction easy to operate. Interestingly, chalcones undergo $(2+2)$ cycloaddition themselves under thermal conditions to produce cyclobutane derivatives, whose structures are confirmed by XRD studies [26,27]. The regioselective synthesis of 1-alkyl-2-aryl-3-acyl pyrrolo[2,3-b]quinoxalines through Heck coupling reaction/heteroannulation was achieved by the $\operatorname{Pd}(\mathrm{OAc})_{2}$ catalyzed reaction of $N$-alkyl/benzyl-3-chloroquinoxaline-2-amines with chalcones in the presence of $\mathrm{KO}^{\mathrm{t}} \mathrm{Bu}$ in DMSO (Scheme 4) [28]. Chalcones efficiently undergo (3+2) annulation reaction with 2-aminothiophenol in the presence of acids to give benzothiazepines [29,30].

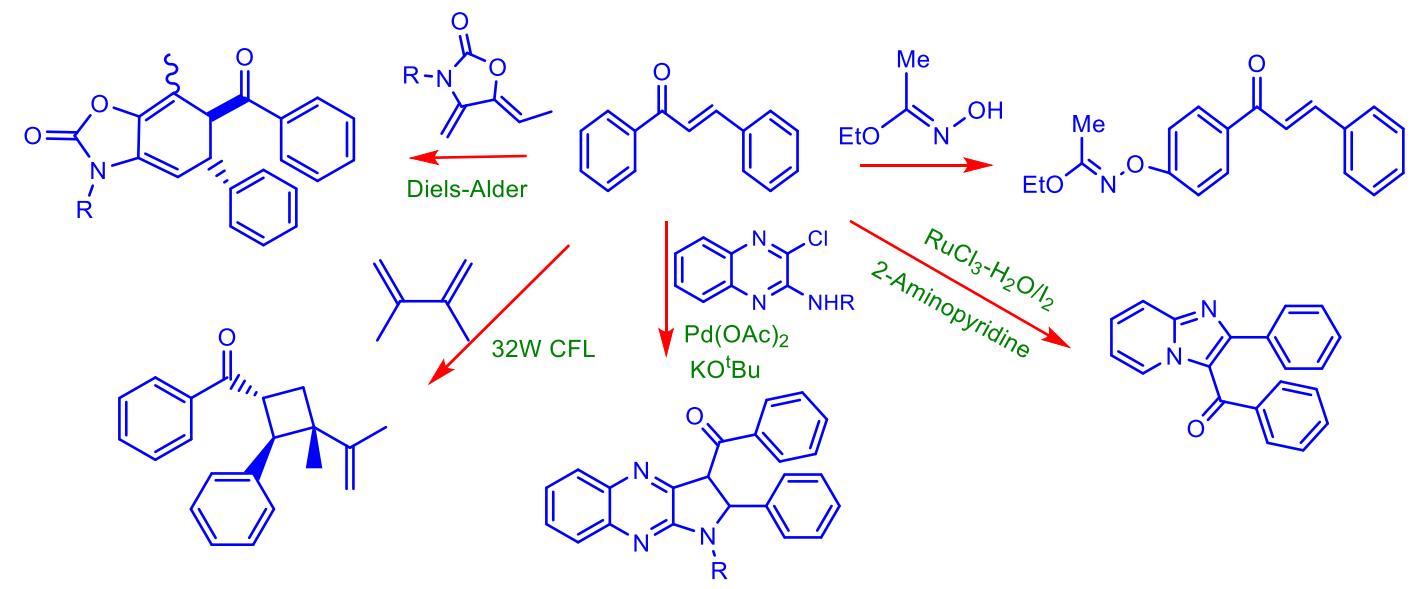

Scheme 4. Synthesis of functionalised compounds from chalcones.

A simple and efficient protocol for preparing densely functionalized 3aroylimidazo[1,2-a]pyridines from 2-aminopyridines and chalcones using $\mathrm{RuCl}_{3}-\mathrm{H}_{2} \mathrm{O} / \mathrm{I}_{2}$ catalytic system was reported [31]. The method's advantages are low catalyst loading, broad substrate scope, stability of heterocycles, operationally simple procedure, and higher yields, making the approach remarkable. Heteroaryl chalcones found more susceptible to form pyrazole derivatives $[32,33]$ by their reaction with hydrazines

\section{Pharmacological Applications}

Chalcone, a natural structure, demonstrates many pharmacological activities, including anti-cancer, antidiabetic, antimicrobial, anti-inflammatory, antitumor, anti-Alzheimer, etc., and plays pivotal roles in medicinal chemistry [34]. In cancer chemotherapy, multidrug resistance (MDR) is highly associated with ATP-binding cassette transport proteins' overexpression. The translocation of drugs from the inside to the outside of cancer cells is mediated at the expense of ATP. The chalcone-dithiocarbamate hybrids, of which (E)-2-oxo- 
2-((4-(3-(3,4,5-trimethoxyphenyl)acryloyl)phenyl)amino)ethyl-4-(2-hydroxyethyl)piperazine1-carbodithioate (Fig. 1A) exhibited antiproliferative activity against MCF7, and PC3 $\left(\mathrm{IC}_{50}=1.05 \mu \mathrm{M}\right)$ cancer cell lines [35]. The cellular mechanism indicated that it could inhibit colony formation, arrest cell cycle at G2/M phase, induce DNA damage against PC3 cells, and mitochondrial apoptosis by caspase activation, and therefore would be a lead for treatment of human prostate cancer. The xanthine/chalcone hybrids, of which chalcone derivative (Fig. 1B) [36] acts as anti-cancer agents with potent inhibition of cancer cell growth (IC50: $1.0 \pm 0.1$ to $3.5 \pm 0.4 \mu \mathrm{M})$. Further, its EGFR inhibitory effect shown that $\mathrm{IC}_{50}=0.3 \mu \mathrm{M}$ on the target enzyme was more potent than staurosporine reference drug $\left(\mathrm{IC}_{50}=0.4 \mu \mathrm{M}\right)$. The $4^{\prime}$-alkoxy chalcones possess antiproliferative activity against PC-3, MCF-7, and HF-6 with IC50 values of 8.08 to $13.75 \mu \mathrm{M}$ [37].

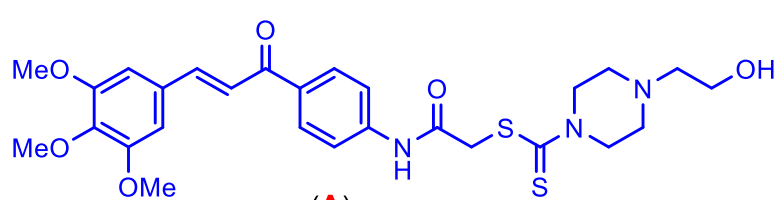

(A)

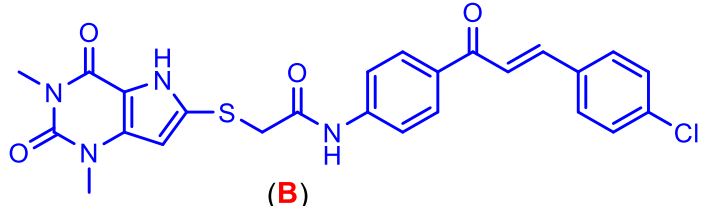

(B)

Figure 1. A) Chalcone-piperazine-1-carbodithioate that shows antiproliferative activity; B) xanthine/chalcone hybrid that possesses EGFR inhibitory effect.

The chalcone derivative (Fig. 2A) [38] bearing an $\alpha, \beta$-unsaturated ketone acts as the most potent inhibitor against NCI-H460, A549, and H1975 cells. It has antiproliferative ability against NCI-H460 cells in a time- and concentration-dependent manner through modulating ROS to induce caspase-3-mediated pyroptosis. The chalcone (Fig. 2B) induced apoptosis of human hepatic and lung cancer cells, which prevented cancer cell migration and invasion. It strongly suppressed tumor growth in a mouse model of xenograft tumors [39]. The pyrazoles derived from chalcones have excellent anti-cancer properties [40]. The enhancement of drug efflux caused by ATP-binding cassette transporters overexpression is an important factor for multidrug resistance (MDR) in cancers. It was found that chalcone and bis-chalcone derivatives displayed the reversal activities of MDR cancer cell lines. The chalcone (Fig. 2C) exhibited the most potent reversal activities against ABCG2- and ABCB1-mediated MDR [41]. The mechanistic studies indicate that it can increase anti-cancer drugs in ABCG2- and ABCB1overexpressing cancer cell lines.<smiles>C=CC(=O)Nc1ccc(C(=O)/C=C/c2ccccc2Cl)cc1</smiles><smiles>COc1cc(C(=O)/C=C/c2ccc(OC)c(OC)c2)ccc1O</smiles><smiles>COc1ccc(/C=C/C(=O)c2ccc(OC)c(OC)c2)c(OC)c1</smiles>

(A)

(B)

(C)

Figure 2. The chalcone analogs with: A) antiproliferative activity against NCI-H460 cells; B) induced apoptosis of human hepatic and lung cancer cells; C) reversal activities against ABCG2- and ABCB1-mediated MDR.

Overexpression of P-glycoprotein (P-gp) is one of the major causes of multidrug resistance (MDR), which has become a major obstacle in cancer therapy. The compound (Fig. $3 \mathrm{~A})$ [42] displayed the highest activity $(\mathrm{RF}=50.19)$ in reversing DOX resistance in MCF7/DOX cells, and increase the intracellular accumulation of DOX and inhibit the expression of P-gp at mRNA and protein levels. The $\alpha$-substituted chalcones (Fig. 3B) [43] possess markable antiproliferative activities with GI50 values of $0.63 \mu \mathrm{M}$ in the HCC1954 cell line and $0.69 \mu \mathrm{M}$ in HCT116 cell lines, and it overcomes multidrug resistance. The chalcone pyrido[4,3- 
b]pyrazin-5(6H)-one (Fig. 3C) [44] displayed anti-cancer activities against human cancer cell lines such as MCF-7, A-549, Colo-205, A2780, and DU-145 by MTT assay.<smiles>COc1cc(OC)c(C(=O)/C=C/c2cccc(N3CCNCC3)c2)c(O)c1CC=C(C)C</smiles>

(A)<smiles>[R]/C(=C/C(=O)c1ccccc1)c1ccccc1</smiles>

(B)<smiles>[R]c1ccc(C(=O)/C=C/c2ccc(N(CC)C(=O)c3ccccn3)cc2)cc1</smiles>

(C)

Figure 3. The chalcone analogs with: A) reversing DOX resistance; B) antiproliferative activities in HCC1954 cell line; C) anti-cancer activities against human cancer cell lines.

1,3,5-Triazinyl chalcone hybrids (Fig. 4A) inhibited A549 cancer cells viability with $\mathrm{IC}_{50}$ value of $24.5 \mu \mathrm{M}$, about cisplatin $\left(\mathrm{IC}_{50}=21.5 \mu \mathrm{M}\right)$. The combined effect of cisplatin with the compound indicated that the combination with cisplatin promoted more cells to enter late apoptosis and necrosis [45]. 1,2,3-Triazole chalcone hybrids (Fig. 4B) [46] possess admirable cytotoxicity against MCF-7, HeLa, and MDA-MB-231 cell lines with lower IC50 value compared to cisplatin and were less toxic effect on normal cells. The 1,2,4-triazole/chalcone hybrids of which compound (Fig. 4C) has potent cytotoxicity against A549 cancer cell lines with $\mathrm{IC}_{50}$ values of $4.4 \mu \mathrm{M}$. It showed an increase in the number of apoptotic cells in a dosedependent manner and induced apoptosis via an increased level of pro-apoptotic protein $\mathrm{g}$ Bax, the release of cytochrome $c$, and activation of caspase-3/8/9 proteins [47]

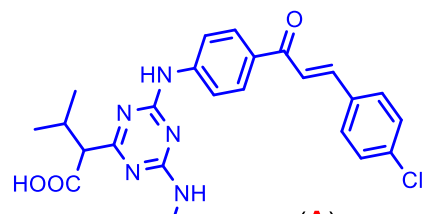

(A)

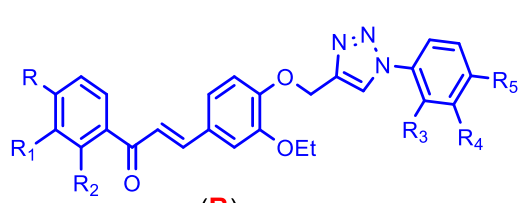

(B)

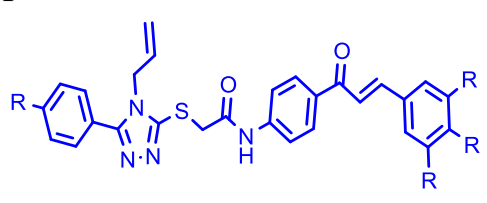

(C)

Figure 4. The chalcones displays; A) inhibition against A549 cells; B) cytotoxicity against MCF-7, HeLa; C) cytotoxicity against A549 cell lines.

Hepatocellular Carcinoma is extremely aggressive and presents low rates of response to chemotherapeutic agents. The quinoline/chalcone/1,2,4-triazole hybrids (Fig. 5A) [48] displayed good activity on different NCI 60 cell lines in a single-dose assay with a growth inhibition rate ranging from $50 \%$ to $94 \%$ and antiproliferative activities against human cancer cell lines. Thienoquinoline carboxamide-chalcones (Fig. 5B) [49] have an antiproliferative effect and acts as EGFR inhibitors with $\mathrm{IC}_{50}$ values of $0.5-3.2 \mu \mathrm{M}$. The binding mode of the EGFR inhibitor in the EGFR active site revealed that the thienoquinoline ring occupied the ATP-binding site while the chalcone moiety is located in the allosteric site is responsible for enhanced activity.
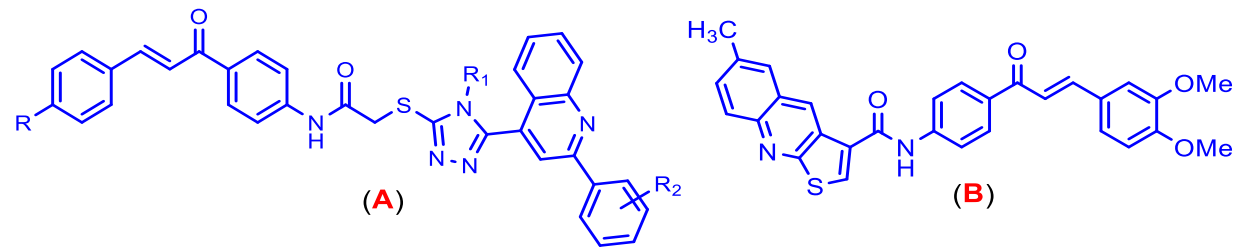

(B)

Figure 5. The chalcones demonstrate: A) antiproliferative activities against NCI 60 cell lines; B) inhibition against EGFR cell lines.

The compounds 1,3,4-oxadiazole/chalcone hybrids have shown promising anti-cancer activity against leukemia. The compound (Fig. 6A) of the series had strong cytotoxic activities with IC50 of $1.95 \mu \mathrm{M}, 2.36 \mu \mathrm{M}$ and $3.45 \mu \mathrm{M}$ against K-562, KG-1a, and Jurkat leukemia cell lines, effectively inhibit EGFR $\left(\mathrm{IC}_{50}=0.24 \mu \mathrm{M}\right)$, Src $\left(\mathrm{IC}_{50}=0.96 \mu \mathrm{M}\right)$, and decreased STAT3 
activation [50]. The sulfonamide chalcone derivative (Fig. 6B) [51] possesses anti-cancer properties at $10 \mu \mathrm{M}$ against sixty human cancer cell lines. It satisfied the pre-determined threshold inhibition criteria. Further, it displayed inhibition against $M$. tuberculosis $\mathrm{H} 37 \mathrm{Rv}$ with MIC values between 14-42 $\mu \mathrm{M}$.
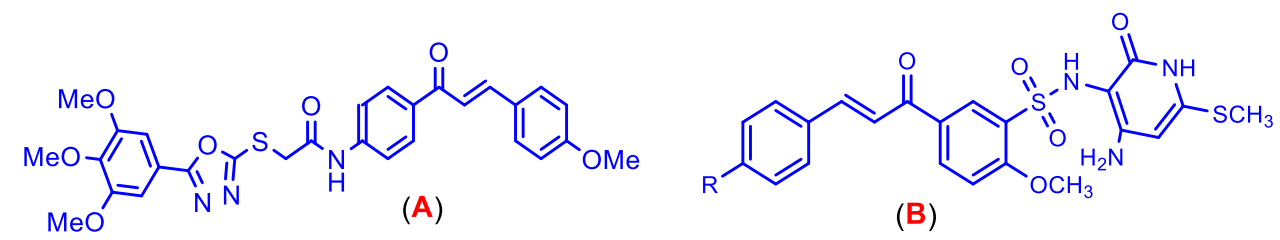

(B)

Figure 6. The chalcones show: A) cytotoxicity against K-562, KG-1a, and Jurkat leukemia cell lines; B) antiproliferative activity against NCI 60 cell lines.

Diabetes mellitus (DM) is a serious chronic metabolic disorder that occurs due to dysfunction of insulin and poor therapeutic approaches. It necessitates discovering novel drugs to control amplified diabetic populations. The amino and hydroxy chalcones with alloxaninduced diabetic rats $(100 \mathrm{mg} / \mathrm{kg})$ indicated their antidiabetic efficacy with decreased blood glucose levels in the diabetic rats compared to control rats [52]. The $\alpha$-amylase inhibitory effect was shown by chalcones (Fig. 7A) $\left(\mathrm{IC}_{50}=1.25 \pm 1.05 \mu \mathrm{M}\right)$, and bis-chalcones (Fig. 7B) $\left(\mathrm{IC}_{50}=2.40 \pm 0.09 \mu \mathrm{M}\right)$ as compared acarbose, the thiomethyl and methoxy groups are effective on the activity [53]. The coumarin-triazole hybrids derived from chalcones demonstrated excellent antidiabetic properties [54].<smiles>COc1ccc(/C=C/C(=O)c2ccc(C)cc2)cc1</smiles>

(A)<smiles>COc1ccc(/C=C/C(=O)/C=C/c2ccc(OC)cc2)cc1</smiles>

(B)

Figure 7. The chalcones displays: A) $\alpha$-amylase inhibitory effect; B) $\alpha$-amylase inhibitory effect.

The chalcones were designed to investigate the antibacterial activity, modulatory potential, and efflux pump inhibition against $S$. aureus multi-resistant strains. Compound $(2 E)-$ 1-(4'-aminophenyl)-3-(phenyl)-prop-2-en-1-one (Fig. 8A) [55] has reduced the MIC of gentamicin by $70 \%$, and on comparison of the effects of the modified antibiotic activity indicate a loss of synergism with gentamicin due to the addition of chlorine to the substance structure. The chalcone-1,2,3-triazole conjugates (Fig. 8B) [56, 57] have exhibited significant efficacy against bacterial and fungal strains, wherein the synergistic effect associated with chalcone and 1,2,3-triazole moieties. The cationic chalcone analogs (Fig. 8C) [58] displayed good bactericidal activity against tested bacteria, including the drug-resistant species. These membrane-active antibacterial compounds did not allow bacteria to develop resistance and exhibited negligible toxicity toward mammalian cells, reduce the viable cell counts in bacterial biofilms effectively and have low toxicity toward mammalian cells. A series of pyrazole-pyran hybrids [59], pyrazole-oxadiazole conjugates [60] derived from chalcones displayed good antimicrobial activities.<smiles>Nc1ccc(C(=O)/C=C/c2ccccc2)cc1</smiles>

(A)<smiles>[R]c1ccccc1C(=O)/C=C/c1ccc(NC(=O)C[N+]([Y])(C)C([Y])(C)C)cc1</smiles>

(B)<smiles>[R]n1cc(COc2c(/C=C/C(=O)c3ccccc3)ccc3ccccc23)nn1</smiles>

(C)

Figure 8. The chalcones shows: A) antibiotic activity; B) antibacterial and antifungal activity; C) bactericidal activity against the drug-resistant species. 
The fungi and mycobacteria are the culprits to cause infectious diseases in human beings. The need of an hour is to develop potent agents that overcome cancer and fungal infections. The synthesized dihydropyrazoles (Fig. 9A) [61] and thienyl-pyrazoles [62] and substituted pyrazoles [63] derived from chalcones showed excellent antifungal and antitubercular activities. Prenyloxylated chalcones display metabolic inhibition against $L$. mexicana and T. cruzi. The studies on leishmanicidal and trypanocidal activity of prenyloxy chalcones (Fig. 9B), and (Fig. 9C) [64] exerted metabolic inhibition for L. mexicana, and for T. cruzi; with selectivity index $\left(\mathrm{SI}=\mathrm{IC}_{50} / \mathrm{CC}_{50}\right)$ values of $80.9,1.24$, and $75.1,1.43 \mu \mathrm{M}$, respectively.

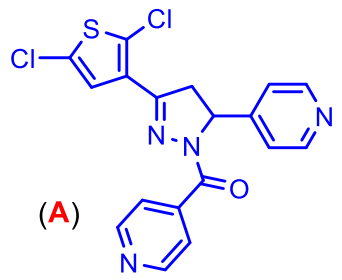

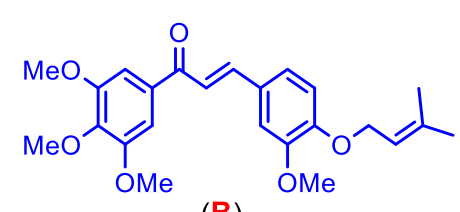

(B)

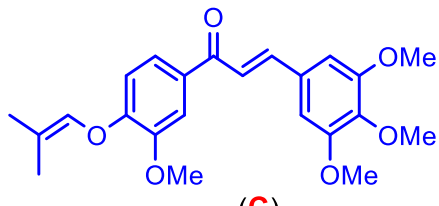

(C)

Figure 9. The chalcones exert: A) antitubercular activity; B) metabolic inhibition for T. cruzi; C) metabolic inhibition for L. mexicana.

Alzheimer's disease (AD) is a common neurodegenerative disease characterized by progressive degeneration and neuronal cell death, resulting in neural network dysfunction. The underlying mechanisms, oxidative damage, and neuroinflammation have contributed to the deterioration of $\mathrm{AD}$. The Nrf2, a transcription factor, regulates the cellular redox balance and is primarily involved in anti-inflammatory responses and is a pivotal cellular defense mechanism against oxidative stress. The lignan conjugates [65], pyrazoles [66], and oxadiazoles/thiadiazoles [67] prepared from various chalcones exhibited markable antioxidant activities comparable to ascorbic acid. The chalcone derivatives (Fig. 10A) [68] found a highly potent Nrf2 activator, which activates Nrf2 and induces expression of the Nrf2-dependent enzymes HO-1 and GCLC at both mRNA and protein levels, and also suppressed the production of nitric oxide and downregulated inflammatory mediators in BV-2 microglial cells. The chalcone-Mannich base analogs of which the compound (Fig. 10B) [69] exerted potent multifunctional properties, viz. inhibits $\mathrm{AChE}\left(\mathrm{IC}_{50}=0.44 \mu \mathrm{M}\right)$ and $\mathrm{MAO}-\mathrm{B}\left(\mathrm{IC}_{50}=1.21 \mu \mathrm{M}\right)$, self-induced $\mathrm{A} \beta 1-42$ aggregation $(55.0 \%, 25 \mu \mathrm{M})$, and also antioxidant activity.<smiles>CN1CCN(C(=O)COc2ccc(C(=O)/C=C/c3ccccc3C(F)(F)F)cc2)CC1</smiles><smiles>CCN(CC)Cc1ccc(/C=C/C(=O)c2ccc(OC)c(OC)c2)cc1O</smiles>

(B)

Figure 10. The chalcones exhibit; A) potent Nrf2 activator; B) inhibits AChE and MAO-B.

Amongst the chalcone- $O$-alkylamine derivatives, compound (Fig. 11A) [70] exhibited a good inhibitory effect on acetylcholinesterase $\left(\mathrm{IC}_{50}=1.3 \mu \mathrm{M}\right)$ and butyrylcholinesterase $\left(\mathrm{IC}_{50}=1.2 \mu \mathrm{M}\right)$. Selective MAO-B $\left(\mathrm{IC}_{50}=0.57 \mu \mathrm{M}\right)$, also showed antioxidant and neuroprotectant activity, indicating that it might be a potential multifunctional agent for $\mathrm{AD}$ treatment. The compound (Fig. 11B) [71] has inhibited selective BuChE $\left(\mathrm{IC}_{50}=2.6 \mu \mathrm{M}\right)$ and MAO-B $\left(\mathrm{IC}_{50}=5.3 \mu \mathrm{M}\right)$. It also showed good antioxidant and neuroprotectant properties. A series of benzothiazepines derived from furanyl chalcones potently inhibited VRV-PL-8a and $\mathrm{H}^{+} / \mathrm{K}^{+}$ATPase [72]. 

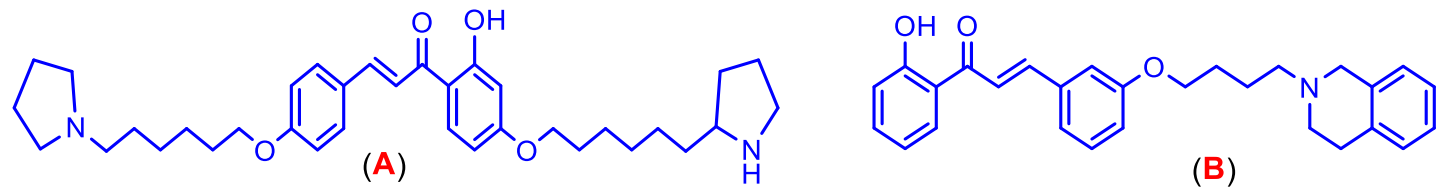

(B)

Figure 11. The chalcones; A) inhibit acetylcholinesterase; B) inhibits BuChE and MAO-B.

Ferroptosis is associated with the accumulation of lipid hydroperoxides and amyloid cascade hypothesis, the main forms of cell death in Alzheimer's disease. Hydroxylated chalcones (Fig. 12A) [73] inhibited amyloid- $\beta$ peptide $(\mathrm{A} \beta)$ aggregation and ferroptosis simultaneously. In human neuroblastoma SH-SY5Y cells, these chalcones exhibit neuroprotection against $A \beta_{1-42}$ aggregation-induced toxicity and are good inhibitors of ferroptosis induced by the hydroperoxide-detoxifying enzyme Gpx4 using cystine/glutamate antiporter system. The $\left[{ }^{18} \mathrm{~F}\right] 4$-dimethylamino-4'-fluoro-chalcone (Fig. 12B) [74] showed a higher initial uptake $(4.43 \% \mathrm{ID} / \mathrm{g}$ at $2 \mathrm{~min})$ into and more rapid clearance $(0.52 \%$ $\mathrm{ID} / \mathrm{g}$ at $30 \mathrm{~min}$ ) from the brain than FDA-approved drugs, indicating the improvement of the probability of detecting $A \beta$ plaques and the reduction of non-specific binding in the brain. The series of 4'-OH-flurbiprofen-chalcone hybrids (Fig. 12C) [75] exhibited good multifunctional activities, showing the best inhibitory effects on self-induced $\mathrm{A} \beta_{1-42}$ aggregation $(60.0 \%$ and $78.2 \%$, ) and $\mathrm{Cu}^{2+}$-induced $\mathrm{A} \beta_{1-42}$ aggregation $(52.4 \%$ and $95.0 \%)$ and therefore these are promising candidate against $\mathrm{AD}$.<smiles>Cc1cccc(/C=C/C(=O)c2ccc(O)c(O)c2O)c1</smiles>

(A)<smiles>CN(C)c1ccc(/C=C/C(=O)c2ccc(F)cc2)cc1</smiles>

(B)

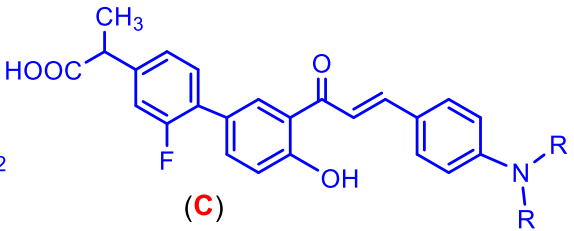

(C)

Figure 12. The chalcones possess; $A)$ inhibit amyloid- $\beta$ peptide $(A \beta)$ aggregation; $B)$ probable detection of $A \beta$ plaques; $\mathrm{C}$ ) inhibitory effects on self-induced $\mathrm{A} \beta_{1-42}$ aggregation.

The development of novel neuroprotective agents is urgently needed to treat neurodegenerative diseases affecting aging individuals worldwide. The set of chalcone-triazole hybrids (Fig. 13A) [76] displayed neuroprotection in oxidative stress-induced neuronal cell damage, significantly improved neurons' morphology, and increased the cell survival rate of neuronal cells induced by oxidative stress, and promoted neuroprotection via the SIRTFOXO3a signaling pathway. The oxygenated chalcones (Fig. 13B) [77] have their abilities to inhibit monoamine oxidases, in particular against MAO-B with an $\mathrm{IC}_{50}$ value of 0.0021 $0.0034 \mu \mathrm{M}$, and against MAO-A with an $\mathrm{IC}_{50}$ value of $0.029-0.072 \mu \mathrm{M}$. Oxidative stressinduced degeneration of retinal pigment epithelial cells is known to be a key contributor to the development of age-related macular degeneration (AMD). The pyrazoline derived from chalcones through $(3+2)$ annulation reactions has shown potent affinity anti-inflammatory effect mediated by inhibition of phospholipase A2 [78,79].

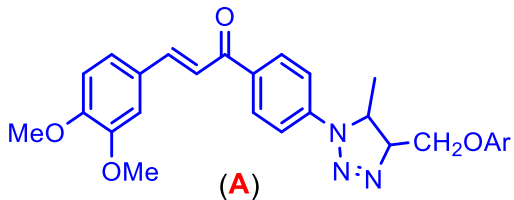

(A)<smiles>[R]c1ccc(C(=O)/C=C/c2ccc3c(c2)O[Al]O3)cc1</smiles>

(B)

Figure 13. The chalcones have; A) neuroprotection in oxidative stress-induced neuronal cell damage; B) inhibits monoamine oxidases. 


\section{Physical properties}

Conformational differences in the chalcone compounds influence their physicalchemical properties, and the comparative structural analysis is relevant to describe changes in their properties. The analysis of three 1-(4-nitrophenyl)-5-(2,6,6-trimethylcyclohex-2-en-1yl)penta-1,4-dien-3-ones shown that the polymorphism can affect the properties [80]. The compound 2E-1-(2'-Hydroxy-3',4',6'-trimethoxyphenyl)-3-(phenyl)-prop-2-en-1-one (Fig. 14A) [81] has shown s. The azo group tethered chalcone (Fig. 14B) [82] showed good dyeing performance on polyester fibers and excellent fastness properties on PET fiber. The chalcone (2E)-1-(3'-methoxy-4'-hydroxyphenyl)-3-(3-nitrophenyl)prop-2-en-1-one (Fig. 14C) [83] displayed good NLO properties. The compound $2(E)-(4-\mathrm{N}, \mathrm{N}-$ dimethylaminobenzylidene $)-5-$ methylcyclohexanone [84], and 3-(benzo[d][1,3]dioxol-5-yl)-1-(3-chlorophenyl)-5-(2,4dichlorophenyl)-4,5-dihydro-1H-pyrazole [85] derived from chalcone showed good optical properties.<smiles>COc1cc(OC)c(O)c(C(=O)/C=C/c2ccccc2)c1O</smiles>

(A)<smiles>O=C(/C=C/c1ccccc1)c1ccc(N=NC2C(=O)NC(=S)NC2=O)cc1</smiles>

(B)<smiles>COc1cc(C(=O)/C=C/c2cccc([N+](=O)[O-])c2)ccc1O</smiles>

(C)

Figure 14. The chalcones show; A) electrochemical behavior; B) dyeing performance on polyester fibers; C) non-linear optical properties.

The compounds (E)-3-(4-methoxyphenyl)-1-(p-tolyl)prop-2-en-1-one, and (E)-3-(4(diethylamino)phenyl)-1-(p-tolyl)prop-2-en-1-one have shown good corrosion mitigation of mild steel in $0.5 \mathrm{M} \mathrm{H} \mathrm{H}_{2} \mathrm{SO}_{4}$ medium [86]. The compounds 4-chloro-N- $\{3-[(2 E)-3-$ (methoxyphenyl)prop-2-enoyl]phenyl\}benzamide [87], and pyrazolines derived from chalcones $[88,89]$ indicated that these exhibit good NLO properties and were good material into fabrication for optoelectronic device applications. An oligo phenylene vinylene was prepared by the anodic oxidation of the 4-dimethylamino-4'-methoxychalcone (Fig. 15A) [90] at a constant potential in nitromethane on a platinum electrode, was thermally stable up to $190^{\circ} \mathrm{C}$, and it displayed optical and electrochemical properties. Tetraphenylene-chalcones hybrids (Fig. 15B) [91] exhibit Stokes shifts and solvation effects and significant fluorescence properties in both solution and solid states.

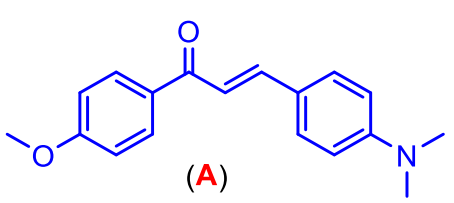

(A)

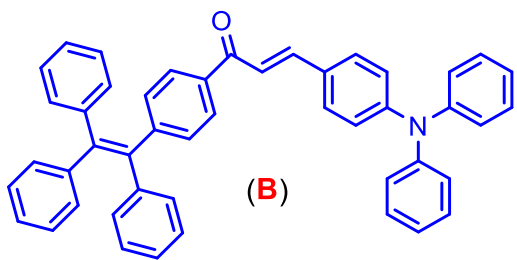

Figure 15. The chalcones exhibit; A) optical and electrochemical properties; B) Stokes shifts and solvation effects.

The chalcones, [(2E)-3-(3-chlorophenyl)-1-(3-nitrophenyl)prop-2-en-1-one and (2E)3-(4-fluorophenyl)-1-(4-nitrophenyl)prop-2-en-1-one and [(2E)-1-(9-anthryl)-3-(4fluorophenyl) prop-2-en-1-one [92] have exhibited third-order nonlinear optical limiting properties, and have some potential sites for electrophilic and nucleophilic attack. 


\section{Conclusions}

The present review summarizes and focuses on the recent developments in the synthesis of chalcones, their versatility as scaffolds in the synthesis of varied classes of compounds of medicinal perspectives, and also describes their structure-activity relationship studies. The discussion on physical properties like semiconductor, optical, and fluorescence properties explores the diverse applications in photosensing and optical switching devices. The structure and structural optimization is promising for potential drug design and discovery, and development. The critical discussion made on anti-cancer, antidiabetic, antimicrobial, antiinflammatory, antioxidant, anti-Alzheimer activities of chalcones in this review may surely help, particularly the young researchers working in this area.

\section{Funding}

This research received no external funding.

\section{Acknowledgments}

The authors are grateful to Prof. K.M. Lokanatha Rai (Retired), Department of Chemistry, University of Mysore, Mysore, for his help in the manuscript preparation and proofreading.

\section{Conflicts of Interest}

The authors declare no conflict of interest.

\section{References}

1. Rashid, H.; Xu, Y.; Ahmad, N.; Muhammad, Y.; Wang, L. Promising anti-inflammatory effects of chalcones via inhibition of cyclooxygenase, prostaglandin $\mathrm{E}_{2}$, inducible NO synthase and nuclear factor $\kappa \mathrm{b}$ activities. Bioorganic Chemistry 2019, 87, 335-365, https://doi.org/10.1016/j.bioorg.2019.03.033.

2. Vagish, C.B.; Kumar, A.D.; Kumara, K.; Vivek, H.K.; Renuka, N.; Lokanath, N.K.; Kumar, K.A. Environmentally benign synthesis of substituted pyrazoles as potent antioxidant agents, characterization and docking studies, Journal of Iranian Chemical Society 2021, 18 479-493, https://doi.org/10.1007/s13738-02002042-6.

3. Kumar, A.; Rout, L.; Achary, L.S.K.; Mohanty, S.K.; Nayak, P.S.; Barik, B.; Dash, P. Solvent free synthesis of chalcones over graphene oxide-supported $\mathrm{MnO}_{2}$ catalysts synthesized via combustion route, Material Chemistry and Physics 2021, 259, 124019, https://doi.org/10.1016/j.matchemphys.2020.124019.

4. Adnan, D.; Singh, B.; Mehta, S.K.; Kumar, V.; Kataria, R. Simple and solvent free practical procedure for chalcones: An expeditious, mild and greener approach, Current Research in Green and Sustainable Chemistry 2020, 3, 100041, https://doi.org/10.1016/j.crgsc.2020.100041.

5. Burmaoglu, S.; Yilmaz, A.O.; Polat, M.F.; Kaya, R.; Gulcin, I.; Algul, O. Synthesis and biological evaluation of novel tris-chalcones as potent carbonic anhydrase, acetylcholinesterase, butyrylcholinesterase and $\alpha$ glycosidase inhibitors, $\quad$ Bioorganic $\quad$ Chemistry $\quad \mathbf{2 0 1 9}, \quad 85, \quad$ 191-197, https://doi.org/10.1016/j.bioorg.2018.12.035.

6. Lokeshwari, D.M.; Pavithra, G.; Renuka, N.; Lokanath, N.K.; Naveen, S.; Ajay Kumar, K. (E)-1(Benzo[d][1,3]dioxol-5-yl)-3-(2,3-dichlorophenyl)prop-2-en-1-one, IUCrData 2017, 2, x170103, https://doi.org/0.1107/S2414314617001031.

7. Sunitha, V.M.; Naveen, S.; Vagish, C.B.; Ajay Kumar, K.; Lokanath, N.K.; Manjunath, H.R. (E)-3-(2,3dichlorophenyl)-1-(2-methoxyphenyl)prop-2-en-1-one, $\quad$ IUCrData $\quad \mathbf{2 0 1 7}, \quad 2, \quad$ x162056, https://doi.org/10.1107/S2414314616020563.

8. Kumara, K.; Naveen, S.; Dileep Kumar, A.; Ajay Kumar, K.; Lokanath, N.K.; Warad, I. (E)-1-(1,3Benzodioxol-5-yl)-3-[4-(dimethylamino)-phenyl]prop-2-en-1-one, $\quad$ IUCrData $\quad \mathbf{2 0 1 7}, \quad$ 2, $\quad$ x162029, https://doi.org/10.1107/S2414314616020290. 
9. Sunitha, V.M.; Naveen, S.; Dileep Kumar, A.; Ajay Kumar, K.; Lokanath, N.K.; Manivannan, V.; Manjunath, H.R. (E)-1-(Benzo[d][1,3]dioxol-5-yl)-3-(2,4,5-trimethoxyphenyl)prop-2-en-1-one, IUCrData 2017, 2, x162026, https://doi.org/10.1107/S2414314616020265.

10. Lokeshwari, D.M.; Naveen, S.; Prabhudeva, M.G.; Raghavendra, K.R.; Dileep Kumar, A.; Lokanath, N.K.; Ajay Kumar, K. 5-(2,3-Dichlorophenyl)-3-(4-methoxyphenyl)-1-phenyl-4,5-dihydro-1H-pyrazole, IUCrData 2017, 2, x162013, https://doi.org/10.1107/S2414314616020137.

11. Sunitha, V.M.; Naveen, S.; Dileep Kumar, A.; Ajay Kumar, K.; Lokanath, N.K.; Manjunath, H.R. (E)-1-(4Methoxyphenyl)-3-(2,4,5-trimethoxyphenyl)prop-2-en-1-one, IUCrData $\quad \mathbf{2 0 1 6}, \quad 1, \quad \mathrm{x} 161935$, https://doi.org/10.1107/S2414314616019350.

12. Martelli, L.S.R.; Viera, L.C.C.; Paixao, M.W.; Zukerman-Schpector, J.; de Souza, J.O.; Aguiar, A.C.C.; Oliva, G.; Guido, R.V.C.; Correa, 1a.G. Organocatalytic asymmetric vinylogous 1,4-addition of $\alpha, \alpha$ Dicyanoolefins to chalcones under a bio-based reaction media: Discovery of new Michael adducts with antiplasmodial activity. Tetrahedron 2019, 75, 3530-3542, https://doi.org/10.1016/j.tet.2019.05.022.

13. Kumar, A.D.; Vagish, C.; Renuka, N.; Lokeshwari, D.M.; Kumar, K.A. Green synthesis of novel pyrazoline carbothioamides: A potent antimicrobial and antioxidant agents. Chemical Data Collections 2020, 28, 100445, https://doi.org/10.1016/j.cdc.2020.100445.

14. Prabhudeva, M.G.; Vivek, H.K.; Ajay Kumar, K. Synthesis of novel pyrazole carboxamides using reusable catalyst as antimicrobial agents and molecular docking studies. Chemical Data Collections 2019, 20, 100193, https://doi.org/10.1016/j.cdc.2019.100193.

15. Nair, D.; Pavashelrishi, P.; Namboothiri, I.N.N. 1,3-Dipolar cycloaddition of chalcones and arylidene-1,3dicarbonyls with diazosulfone for the regioselective synthesis of functionalized pyrazoles and pyrazolines. Tetrahedron 2018, 74, 2716-2724, https://doi.org/10.1016/j.tet.2018.04.030.

16. Raghavendra, K.R.; Prabhudeva, M.G.; Dileep Kumar, A.; Ajay Kumar, K.; Jayadevappa, H.P. IsoxazolesA biocompatible radical scavenging agents: Citrus juice mediated environmentally benign synthesis and characterization. Asian Journal of Chemistry 2020, 32, 2997-3001, https://doi.org/10.14233/ajchem.2020.22871

17. Agrawal, N.; Mishra, P. The synthetic and therapeutic expedition of isoxazole and its analogs. Medicinal Chemistry Research 2018, 27, 1309-1344, https://doi.org/10.1007/s00044-018-2152-6.

18. Vagish, C.B.; Renuka, N.; Ajay Kumar, K.; Jayadevappa, H.P. Synthesis of thienyl-isoxazolines and in vitro screening for their antimicrobial activity. Asian Journal of Organic and Medicinal Chemistry 2020, 5, 208212, https://doi.org/0.14233/ajomc.2020.AJOMC-P277.

19. C.-D. Li, X. Tang, X.-L. He, S. Xue, J.-H. Xu, Y.-J. Li, Copper-catalyzed formation of indolizine derivatives via one-pot reactions of chalcones, benzyl bromides and pyridines. Tetrahedron 2020, 76, 131347, https://doi.org/10.1016/j.tet.2020.131347.

20. Reeta,; Rajendran, V.; Rangarajan, T.M.; Ayushee,; Singh, R.P.; Singh, M. Synthesis of novel chalcones through palladium-catalyzed C-O cross-coupling reaction of bromo-chalcones with ethyl acetohydroxamate and their antiplasmodial evaluation against Plasmodium falcipuram in vitro. Bioorganic Chemistry 2019, 86, 631-640, https://doi.org/10.1016/j.bioorg.2019.02.016.

21. de Castro, M.R.C.; Naves, R.F.; Bernardes, A.; da Silva, C.C.; Perez, C.N.; Moura, A.F.; de Moraes, M.O.; Martins, F.T. Tandem chalcone-sulfonamide hybridization, cyclization and further Claisen-Schmidt condensation: Tuning molecular diversity through reaction time and order and catalyst. Arabian Journal of Chemistry 2020, 13, 1345-1354, https://doi.org/10.1016/j.arabjc.2017.11.005.

22. Mastachi-Loza, S.; Ramirez-Candelero, T.I.; Tapia-Bustamante, A.; Gonzalez-Romero, C.; Diaz-Torres, E.; Tamariz, J.; Toscano, R.A.; Fuentes-Benites, A. Synthesis of 4,5,6,7-tetrahydrobenzoxazol-2-ones by a highly regioselective Diels-Alder cycloaddition of exo-oxazolidin-2-one dienes with chalcones. Tetrahedron Letters 2019, 60, 1370-1374, https://doi.org/10.1016/j.tetlet.2019.04.027.

23. Ajay Kumar, K.; Lokanatha Rai, K.M.; Umesha, K.B. Synthesis and evaluation of antifungal and antibacterial activity of ethyl 3,5-diarylisoxazole-4-carboxylates. Journal of Chemical Research (S) 2001, 436-438, https://doi.org/10.3184/030823401103168389.

24. Ajay Kumar, K.; Lokanatha Rai, K.M.; Umesha, K.B. A new approach for the transformation of alkenes to pyrrolines via aziridine intermediates. Tetrahedron 2001, 57, 6993-6996, https://doi.org/10.1016/S00404020(01)00612-3.

25. Tang, F.; Tang, L.; Guan, Z.; He, Y.-H. Intermolecular [2+2] photocycloaddition of chalcones with 2,3dimethyl-1,3-butadiene under neat reaction conditions, Tetrahedron 2018, 74, 6694-6703, https://doi.org/10.1016/j.tet.2018.09.060. 
26. Renuka, N.; Naveen, S.; Raghavendra, K.R.; Dileep Kumar, A.; Lokanath, N.K.; Ajay Kumar, K. (3,4bis(2,3-dichlorophenyl)cyclobutane-1,2-diyl)bis(furan-2-ylmethanone) monohydrate. IUCrData 2017, 2, x170318, https://doi.org/10.1107/S2414314617003182.

27. Raghavendra, K.R.; Naveen, S.; Renuka, N.; Prabhudeva, M.G.; Lokanath, N.K.; Ajay Kumar, K. 1,3Bis(2,4,5-trimethoxyphenyl)-2,4-bis(p-tolylmethanoyl)cyclobutane. IUCrData $\quad$ 2017, $2, \quad \mathrm{x} 170113$, https://doi.org/10.1107/S2414314617001134.

28. Besharati-Seidani, T.; Keivanloo, A.; Kaboudin, B.; Yoshida, A.; Yokomatsu, T. Regioselective synthesis of 2,3-disubstituted 1-alkyl pyrrolo[2,3-b] quinoxalines through palladium-catalyzed Heck reaction of chalcones and evaluation of their antibacterial activities. Tetrahedron 2018, 74, 2350-2358, https://doi.org/10.1016/j.tet.2018.03.055.

29. Raghavendra, K.R.; Sudeep, P.; Ajay Kumar, K.; Jayadevappa, H.P. An efficient synthesis of thiophene conjugated benzothiazepines: In vitro screening for their antimicrobial activity. Asian Journal of Chemistry 2020, 32, 2601-2605, https://doi.org/10.14233/ajchem.2020.22861.

30. Manjunath, B.C.; Manjula, M.; Raghavendra, K.R.; Shashikanth, S.; Ajay Kumar, K.; Lokanath, N.K. 2-(3,4Dimethoxyphenyl)-4-(thiophen-2-yl)-2,3-dihydro-1,5-benzothiazepine. Acta Crystallographica Section E 2014, 70, o121, https://doi.org/10.1107/S1600536813034612.

31. Ramya, P.V.S.; Angapelly, S.; Digwal, C.S.; Yadav, U.; Babu, B.N.; Kamal, A. An efficient $\mathrm{RuCl}_{3}-\mathrm{H}_{2} \mathrm{O} / \mathrm{I}_{2}$ catalytic system: A facile access to 3-aroylimidazo[1,2-a]pyridines from 2-aminopyridines and chalcones, Journal of Saudi Chemical Society 2018, 22, 90-100, https://doi.org/10.1016/j.jscs.2017.07.007.

32. Prabhudeva, M.G.; Renuka, N.; Kumar, K.A. Synthesis of thiophene-pyrazole conjugates as potent antimicrobial and radical scavengers. Current Chemistry Letters 2018, 7, 73-80, https://doi.org/10.5267/j.ccl.2018.8.001.

33. Mahadevaswamy, L.D.; Kariyappa, A.K. An environmentally benign lemon juice mediated synthesis of novel furan conjugated pyrazole derivatives and their biological evaluation, Pharmaceutical Chemistry Journal 2017, 51, 670-677, https://doi.org/10.1007/s11094-017-1672-6.

34. Prabhu, A.N.; Upadhyaya, A.; Jayarama, A.; Subrahmanya Bhat, K. Third-order NLO property of thienyl chalcone derivative: Physicochemical analysis and crystal structure determination, Molecular Crystals and Liquid Crystals 2016, 637, 76-86, https://doi.org/10.1080/15421406.2016.1177921.

35. Fu, D.-J.; Li, J.-H.; Yang, J.-J.; Li, P.; Zhang, Y.-B.; Liu, S.; Li, Z.-R.; Zhang, S.-Y. Discovery of novel chalcone-dithiocarbamates as ROS-mediated apoptosis inducers by inhibiting catalase. Bioorganic Chemistry 2019, 86, 375-385, https://doi.org/10.1016/j.bioorg.2019.01.023.

36. Abou-Zeid, H.A.; Youssif, B.G.M.; Mohamed, M.F.A.; Hayallah, A.M.; Abdel-Aziz, M. EGFR inhibitors and apoptotic inducers: Design, synthesis, anti-cancer activity and docking studies of novel xanthine derivatives carrying chalcone moiety as hybrid molecules, Bioorganic Chemistry 2019, 89, 102997 , https://doi.org/10.1016/j.bioorg.2019.102997.

37. Marquinaa, S.; Maldonado-Santiagoa, M.; Sanchez-Carranzab, J.N.; Antunez-Mojicaa, M.; GonzalezMayab, L.; Razo-Hernandezc, R.S.; Alvareza, L. Design, synthesis and QSAR study of 2'-hydroxy-4'-alkoxy chalcone derivatives that exert cytotoxic activity by the mitochondrial apoptotic pathway. Bioorganic Medicinal Chemistry 2019, 27, 43-54, https://doi.org/10.1016/j.bmc.2018.10.045.

38. Zhu, M.; Wang, J.; Xie, J.; Chen, L.; Wei, X.; Jiang, X.; Bao, M.; Qiu, Y.; Chen, Q.; Li, W.; Jiang, C.; Zhou, X.; Jiang, L.; Qiu, P.; Wu, J. Design, synthesis, and evaluation of chalcone analogues incorporate $\alpha, \beta$ Unsaturated ketone functionality as anti-lung cancer agents via evoking ROS to induce pyroptosis. European Journal of Medicinal Chemistry 2018, 157, 1395-1405, https://doi.org/10.1016/j.ejmech.2018.08.072.

39. Dong, N.; Liu, X.; Zhao, T.; Wang, L.; Li, H.; Zhang, S.; Li, X.; Bai, X.; Zhang, Y.; Yang, B. Apoptosisinducing effects and growth inhibitory of a novel chalcone, in human hepatic cancer cells and lung cancer cells. Biomedicine \& Pharmacotherapy 2018, 105, 195-203, https://doi.org/10.1016/j.biopha.2018.05.126.

40. Kumar, A.D.; Bharath, S.; Dharmappa, R.N.; Naveen, S.; Lokanath, N.K.; Kumar, K.A. Design, synthesis and spectroscopic and crystallographic characterisation of novel functionalized pyrazole derivatives: biological evaluation for their cytotoxic, angiogenic and antioxidant activities. Research on Chemical Intermediates, 2018, 44, 5635-5652, https://doi.org/10.1007/s11164-018-3445-6.

41. Cai, C.-Y.; Zhang, W.; Wang, J.-Q.; Lei, Z.-N.; Zhang, Y.-K.; Wang, Y.-J.; Gupta, P.; Tan, C.-P.; Wang, B.; Chen, Z.-S. Biological evaluation of non-basic chalcone CYB-2 as a dual ABCG2/ABCB1 inhibitor. Biochemical Pharmacolology 2020, 175, 113848, https://doi.org/10.1016/j.bcp.2020.113848. 
42. Yin, H.; Dong, J.; Cai, Y.; Shi, X.; Wang, H.; Liu, G.; Tang, Y.; Liu, J.; Ma, L. Design, synthesis and biological evaluation of chalcones as reversers of P-glycoprotein-mediated multidrug resistance. European Journal of Medicinal Chemistry 2019, 180, 350-366, https://doi.org/10.1016/j.ejmech.2019.05.053.

43. Riaz, S.; Iqbal, M.; Ullah, R.; Zahra, R.; Chotana, G.A.; Faisal, A.; Saleem, R.S.Z. Synthesis and evaluation of novel $\alpha$-substituted chalcones with potent anti-cancer activities and ability to overcome multidrug resistance. Bioorganic Chemistry 2019, 87, 123-135, https://doi.org/10.1016/j.bioorg.2019.03.014.

44. Srilaxmi, D.; Sreenivasulu, R.; Mak, K.-K.; Pichika, M.R.; Jadav, S.S.; Ahsan, M.J.; Rao, M.V.B. Design, synthesis, anti-cancer evaluation and molecular docking studies of chalcone linked pyrido[4,3-b]pyrazin5(6H)-one derivatives. Journal of Molecular Structure 2021, 1229, 129851, https://doi.org/10.1016/j.molstruc.2020.129851.

45. El-Wakil, M.H.; Khattab, S.N.; El-Yazbi, A.F.; El-Nikhely, N.; Soffar, A.; Khalil, H.H. New chalconetethered 1,3,5-triazines potentiate the anti-cancer effect of cisplatin against human lung adenocarcinoma A549 cells by enhancing DNA damage and cell apoptosis. Bioorganic Chemistry 2020, 105, 104393, https://doi.org/10.1016/j.bioorg.2020.104393.

46. Gurrapu, N.; Kumar, E.P.; Kolluri, P.K.; Putta, S.; Sivan, S.K.; Subhashini, N.J.P. Synthesis, biological evaluation and molecular docking studies of novel 1,2,3-triazole tethered chalcone hybrids as potential anticancer agents. Journal of Molecular Structure $\mathbf{2 0 2 0 ,} \quad 1217, \quad 128356$, https://doi.org/10.1016/j.molstruc.2020.128356.

47. Ahmed, F.F.; Abd El-Hafeez, A.A.; Abbas, S.H.; Abdelhamid, D.; Abdel-Aziz, M. New 1,2,4-triazoleChalcone hybrids induce Caspase-3 dependent apoptosis in A549 human lung adenocarcinoma cells. European Journal of Medicinal Chemistry 2018, 151, 705-722, https://doi.org/10.1016/j.ejmech.2018.03.073.

48. Mohassab, A.M.; Hassan, H.A.; Abdelhamid, D.; Gouda, A.M.; Youssif, B.G.M.; Tateoshi, H.; Fujita, M.; Otsuka, M.; Abdel-Aziz, M. Design and synthesis of novel quinoline/chalcone/1,2,4-triazole hybrids as potent antiproliferative agent targeting EGFR and BRAF ${ }^{\mathrm{V} 600 \mathrm{E}}$ kinases. Bioorganic Chemistry 2021, 106, 104510, https://doi.org/10.1016/j.bioorg.2020.104510.

49. Abdelbaset, M.S.; Abdel-Aziz, M.; Ramadan, M.; Abdelrahman, M.H.; Bukhari, S.N.A.; Ali, T.F.S.; AbuoRahma, G.E-D.A. Discovery of novel thienoquinoline-2-carboxamide chalcone derivatives as antiproliferative EGFR tyrosine kinase inhibitors. Bioorganic \& Medicinal Chemistry 2019, 27, 1076-1086, https://doi.org/10.1016/j.bmc.2019.02.012.

50. Fathi, M.A.A.; El-Hafeez, A.A.A.; Hamid, D.A.; Abbas, S.H.; Montano, M.M.; Abdel-Aziz, M. 1,3,4oxadiazole/chalcone hybrids: Design, synthesis, and inhibition of leukemia cell growth and EGFR, Src, IL-6 and STAT3 activities. Bioorganic Chemistry 2019, 84, 150-163, https://doi.org/10.1016/j.bioorg.2018.11.032.

51. Castano, L.F.; Cuartas, V.; Bernal, A.; Insuasty, A.; Guzman, J.; Vidal, O.; Rubio, V.; Puerto, G.; Lukac, P.; Vimberg, V.; Balikova-Novtona, G.; Vannucci, L.; Janata, J.; Quiroga, J.; Abonia, R.; Nogueras, M.; Cobo, J.; Insuasty, B. New chalcone-sulfonamide hybrids exhibiting anticancer and antituberculosis activity. European Journal of Medicinal Chemistry 2019, 176, 50-60, https://doi.org/10.1016/j.ejmech.2019.05.013.

52. Rammohan, A.; Bhaskar, B.V.; Venkateshwarlu, N.; Gu, W.; Zyryanov, G.V. Design, synthesis, docking and biological evaluation of chalcones as promising antidiabetic agents, Bioorganic Chemistry 2020, 95, 103527, https://doi.org/10.1016/j.bioorg.2019.103527.

53. Bale, A.T.; Khan, K.M.; Salar, U.; Chigurupati, S.; Fasina, T.; Ali, F.; Kanwal.; Wadood, A.; Taha, M.; Nanda, S.S.; Ghufran, M.; Perveen, S. Chalcones and bis-chalcones: As potential $\alpha$-amylase inhibitors; synthesis, in vitro screening, and molecular modelling studies. Bioorganic Chemistry 2018, 79, 179-189, https://doi.org/10.1016/j.bioorg.2018.05.003.

54. Vagish, C.B.; Vivek, H.K.; Karthik, K.; Dileep, K.A.; Lokanath. N.K.; Ajay, K.K. Design and synthesis of novel coumarin-triazole hybrids: Biocompatible antidiabetic agents, in silico molecular docking and ADME screening. Heliyon 2020, 6, e05290, https://doi.org/10.1016/j.heliyon.2020.e05290.

55. Siqueira, M.M.R.; Freire, P.de T.C.; Cruz, B.G.; Freitas, T.S.; Bandeira, P.N.; dos Santos, H.S.; Nogueira, C.E.S.; Teixeira, A.M.R.; Pereira, R.L.S.; da Cunha Xavier, J.; Campina, F.F.; Barbosa, C.R.S.; de Arauho Neto, J.B.; Silva, M.M.C.; Siqueira-Junior, J.P.; Coutinho, H.D.M. Aminophenyl chalcones potentiating antibiotic activity and inhibiting bacterial efflux pump. European Journal of Pharmaceutical Sciences 2021, 158, 105695, https://doi.org/10.1016/j.ejps.2020.105695. 
56. Yadav, P.; Lal, K.; Kumar, L.; Kumar, A.; Kumar, A.; Paul, A.K.; Kumar, R. Synthesis, crystal structure and antimicrobial potential of some fluorinated chalcone-1,2,3-triazole conjugates, European Journal of Medicinal Chemistry 2018, 155, 263-274, http://doi.org/10.1016/j.ejmech.2018.05.055.

57. Sudeep, P.; Vagish, C.B.; Dileep Kumar, A.; Ajay Kumar, K. 1,2,3-Triazoles: A review on current trends in synthetic and biological applications. IOSR Journal of Applied Chemistry 2020, 13, 22-40, https://doi.org/10.9790/5736-1308012240.

58. Chu, W.-C.; Bai, P.-Y.; Yang, Z.-Q.; Cui, D.-Y.; Hua, Y.-G.; Yang, Y.; Yang, Q.-Q.; Zhang, E.; Qin, S. Synthesis and antibacterial evaluation of novel cationic chalcone derivatives possessing broad spectrum antibacterial activity. European Journal of Medicinal Chemistry 2018, 143, 905-921, https://doi.org/10.1016/j.ejmech.2017.12.009.

59. Gurunanjappa, P.; Ningappa, M.B.; Kariyappa, A.K. Synthesis of pyrazole fused pyran analogues: Antimicrobial, antioxidant and molecular docking studies. Chemical Data Collections, 2016, 5-6, 1-11, https://doi.org/10.1016/j.cdc.2016.09.002.

60. Gurunanjappa, P.; Kariyappa, A.K. Design, synthesis and biological evaluation of 1,3,4oxadiazoles/thiadiazoles bearing pyrazole scaffold as antimicrobial and antioxidant candidates. Current Chemistry Letters, 2016, 5, 109-122, https://doi.org/10.5267/j.ccl.2016.2.002.

61. Shaik, A.B.; Bhandare, R.R.; Nissankararao, S.; Edis, Z.; Tangirala, N.R.; Shahanaaz, S,; Rahman, M.M. Design, Facile Synthesis and characterization of dichloro substituted chalcones and dihydropyrazole derivatives for their antifungal, antitubercular and antiproliferative activities. Molecules 2020, 25, 3188, https://doi.org/10.3390/molecules25143188.

62. Prabhudeva, M.G.; Kumara, K.; Kumar, A.D.; Ningappa, M.B.; Lokanath, N,K.; Kumar, K.A. Amberlyst-15 catalyzed synthesis of novel thiophene-pyrazoline derivatives: spectral and crystallographic characterization and anti-inflammatory and antimicrobial evaluation, Research on Chemical Intermediates 2018, 44, 64536468, https://doi.org/10.1007/s11164-018-3501-2.

63. Lokeshwari, D.M.; Kumar, K.A. Synthesis of isoxazoles via 1,3-dipolar cycloaddition reactions: Pharmacological screening for their antioxidant and antimicrobial activities, Asian Journal of Chemistry, 2017, 29, 2660-2664, https://doi.org/10.14233/ajchem.2017.20781.

64. Espinozo-Hicks, J.E.; Chacon-Vargas, K.F.; Hernandez-Rivera, J.L.; Nogueda-Torres, B.; Tamariz, J.; Sanchez-Torres, L.E.; Camacho-Davila, A. Novel prenyloxy chalcones as potential leishmanicidal and trypanocidal agents: Design, synthesis and evaluation, European Journal of Medicinal Chemistry 2019, 167, 402-413, https://doi.org/10.1016/j.ejmech.2019.02.028.

65. Raghavendra, K.R.; Renuka, N.; Kumar, K.A. Shashikanth S. An accessible route for the synthesis of novel lignan derivatives and their biological evaluation. Pharmaceutical Chemistry Journal, 2017, 51, 661-669, https://doi.org/10.1007/s11094-017-1671-7.

66. Naveen, S.; Kumara, K.; Kumar, A.D.; Kumar, K.A.; Zarrouk, A.; Warad, I.; Lokanath, N.K. Synthesis, characterization, crystal structure, Hirshfeld surface analysis, antioxidant properties and DFT calculations of a novel pyrazole derivative: Ethyl 1-(2,4-dimethylphenyl)-3-methyl-5-phenyl-1H-pyrazole-4-carboxylate, Journal of Molecular Structure, 2021, 1226A, 129350, https://doi.org/10.1016/j.molstruc.2020.129350.

67. Renuka, N.; Vivek, H.K.; Pavithra, G.; Ajay Kumar, K. Synthesis of coumarin appended pyrazolyl-1,3,4oxadiazoles and pyrazolyl-1,3,4-thiadiazoles: Evaluation for their in vitro antimicrobial and antioxidant activities and molecular docking studies. Russian Journal Bioorganic Chemistry 2017, 43, 197-210, https://doi.org/10.1134/S106816201702011X.

68. Kim, H.J.; Jant, B.K.; Park, J.-H.; Choi, J.W.; Park, S.J.; Byeon, S.R.; Pae, A.N.; Lee, Y.S.; Cheong, E.; Park, K.D. A novel chalcone derivative as Nrf2 activator attenuates learning and memory impairment in a scopolamine-induced mouse model, European Journal of Medicinal Chemistry 2020, 185, 111777 , https://doi.org/10.1016/j.ejmech.2019.111777.

69. Zhang, X.; Song, Q.; Cao, Z.; Li, Y.; Tian, C.; Yang, Z.; Zhang, H.; Deng, Y. Design, synthesis and evaluation of chalcone Mannich base derivatives as multifunctional agents for the potential treatment of Alzheimer's disease, Bioorganic Chemistry 2019, 87, 395-408, https://doi.org/10.1016/j.bioorg.2019.03.043.

70. Bai, P.; Wang, K.; Zhang, P.; Shi, J.; Cheng, X.; Zhang, Q. Z.; Zheng, C.; Cheng, Y.; Yang, J.; Lu, X.; Sang, Z. Development of chalcone-O-alkylamine derivatives as multifunctional agents against Alzheimer's disease. $\begin{array}{llllll}\text { European Journal of Medicinal } & \text { Chemistry } & \text { 2019, } & 183, & 11737,\end{array}$ https://doi.org/10.1016/j.ejmech.2019.111737. 
71. Sang, Z.; Wang, K.; Zhang, P.; Shi, J.; Liu, W.; Tan, Z. Design, synthesis, in-silico and biological evaluation of novel chalcone derivatives as multi-function agents for the treatment of Alzheimer's disease. European Journal of Medicinal Chemistry 2019, 180, 238-252, https://doi.org/10.1016/j.ejmech.2019.07.021.

72. Lokeshwari, D.M.; Rekha, N.D.; Srinivasan, B.; Vivek, H.K.; Kariyappa, A.K. Design, synthesis of novel furan appended benzothiazepine derivatives and in vitro biological evaluation as potent VRV-PL-8a and $\mathrm{H}^{+} / \mathrm{K}^{+}$ATPase inhibitors. Bioorganic \& Medicinal Chemistry Letters, 2017, 27, 3048-3054, https://doi.org/10.1016/j.bmcl.2017.05.059.

73. Cong, L.; Dong, X.; Wang, Y.; Deng, Y.; Li, B.; Dai, R. On the role of synthesized hydroxylated chalcones as dual functional amyloid- $\beta$ aggregation and ferroptosis inhibitors for potential treatment of Alzheimer's disease. European Journal of Medicinal Chemistry 2019, 166, 11-21, https://doi.org/10.1016/j.ejmech.2019.01.039.

74. Kaide, S.; One, M.; Watanabe, H.; Shimizu, Y.; Nakamoto, Y.; Togashi, K.; Yamaguchi, A.; Hanaoka, H.; Saji, H. Conversion of iodine to fluorine-18 based on iodinated chalcone and evaluation for $\beta$-amyloid PET imaging. Bioorganic \& Medicinal Chemistry 2018, 26, 3352-3358, https://doi.org/10.1016/j.bmc.2018.05.001.

75. Cao, Z.; Yang, J.; Xu, R.; Song, Q.; Zhang, X.; Liu, H.; Quing, X.; Li, Y.; Tan, Z.; Deng, Y. Design, synthesis and evaluation of 4'-OH-flurbiprofen-chalcone hybrids as potential multifunctional agents for Alzheimer's disease treatment. Bioorganic \& Medicinal Chemistry 2018, 26, 1102-1115, https://doi.org/10.1016/j.bmc.2018.01.030.

76. Sooknual, P.; Pingaew, R.; Phopin, K.; Ruankham, W.; Prachayasittikul, S.; Ruchirawal, S.; Prachayasittikul, V. Synthesis and neuroprotective effects of novel chalcone-triazole hybrids. Bioorganic Chemistry 2020, 105, 104384, https://doi.org/10.1016/j.bioorg.2020.104384.

77. Parambi, D.G.T.; Oh, J.M.; Baek, S.C.; Lee, J.P.; Tondo, A.R.; Nicolotti, O.; Kim, H.; Mathew, B. Design, synthesis and biological evaluation of oxygenated chalcones as potent and selective MAO-B inhibitors. Bioorganic Chemistry 2019, 93, 103335, https://doi.org/10.1016/j.bioorg.2019.103335.

78. Lokeshwari, D.M.; Achutha, D.K.; Srinivasan, B.; Shivalingegowda, N.; Krishnappagowda, L.N.; Kariyappa, A.K. Synthesis of novel pyrazole analogues with potent affinity anti-inflammatory effect mediated by inhibition of phospholipase A2: Crystallographic, in silico docking and QSAR analysis. Bioorganic Medicinal Chemistry Letters, 2017, 27, 3806-3811, https://doi.org/10.1016/j.bmcl.2017.06.063.

79. Kumar, A.D.; Prabhudeva, M.G.; Bharath, S.; Kumara, K.; Lokanath, N.K.; Kumar, K.A. Design and Amberlyst-15 mediated synthesis of novel thienyl-pyrazole carboxamides that potently inhibit Phospholipase A2 by binding to an allosteric site on the enzyme. Bioorganic Chemistry, 2018, 80, 444-452, https://doi.org/10.1016/j.bioorg.2018.06.023.

80. Silva, M.C.; Duarte, V.S.; Custodio, J.M.F.; Queiroz, J.E.; de Aquino, G.L.B.; Oliver, A.G.; Napolitano, H.B. Comparative conformational study of a new terpenoid-like chalcone. Journal of Molecular Structure 2021, 1228, 129743, https://doi.org/10.1016/j.molstruc.2020.129743.

81. Teixeira, A.M.R.; Santos, H.S.; Bandeira, P.N.; Juliao, M.S.S.; Freire, P.T.C.; Lima, V.N.; Cruz, B.G.; da Silva, P.T.; Coutinho, H.D.M.; Sena Jr., D.M. Structural, spectroscopic and microbiological characterization of the chalcone 2E-1-(2'-hydroxy-3',4',6'-trimethoxyphenyl)-3-(phenyl)-prop-2-en-1-one derived from the natural product 2-hydroxy-3,4,6-trimethoxyacetophenone. Journal of Molecular Structure 2019, 1179, 739748, https://doi.org/10.1016/j.molstruc.2018.11.075.

82. Omar, A.Z.; Mahmoud, M.N.; El-Sadany, S.K.; Hamed, E.A.; El-Atawy, M.A. A combined experimental and DFT investigation of mono azo thiobarbituric acid based chalcone disperse dye. Dyes and Pigments 2021, 185A, 108887, https://doi.org/10.1016/j.dyepig.2020.108887.

83. Garcia, T.R.; de Freitas, T.S.; dos Santos, H.S.; Bandeira, P.N.; Juliao, M.S.S.; Rocha, J.E.; Nogueira, C.E.S.; Pereira, R.L.S.; Barreto, A.C.H.; Freire, P.T.C.; Coutinho, H.D.M.; Teixeira, A.M.R. Structural, vibrational and electrochemical analysis and antibiotic activity study of chalcone (2E)-1-(3',-methoxy-4',hydroxyphenyl)-3-(3-nitrophenyl)prop-2-en-1-one. Journal of Molecular Structure 2020, 1216, 128358, https://doi.org/10.1016/j.molstruc.2020.128358.

84. Jebapriya, J.C.; Jonathan, D.R.; Kirupavathy, S.S.; Ragu, R.; Prasana, J.C. Growth and characterization of a cyclohexanone based chalcone crystal 2(E)-(4-N,N-dimethylaminobenzylidene)-5-methylcyclohexanone for non-linear optical applications. Optical Materials $\mathbf{2 0 2 0}, 107, \quad 110035$, https://doi.org/10.1016/j.optmat.2020.110035.

85. Shivalingegowda, N.; Kumara, K.; Achutha, D.K.; Kariyappa, A.K.; Krishnappagowda, L.N. Structural elucidation and Hirshfeld Surface Analysis of a novel pyrazole derivative: 3-(Benzo[d][1,3]dioxol-5-yl)-1- 
(3-chlorophenyl)-5-(2,4-dichlorophenyl)-4,5-dihydro-1H-pyrazole. Chemical Data Collections 2018, 15-16, 89-96, https://doi.org/10.1016/j.cdc.2018.04.006.

86. Kumar, B.; Vashisht, H.; Goyal, M.; Kumar, A.; Benhiba, F.; Prasad, A.K.; Kumar, S.; Bahadur, I.; Zarrouk, A. Study of adsorption mechanism of chalcone derivatives on mild steel-sulfuric acid interface. Journal of Molecular Liquids 2020, 318, 113890, https://doi.org/10.1016/j.molliq.2020.113890.

87. Renuka, V.; Revathi, B.K.; Jonathan, D.R.; Priya, M.K.; Asirvatham, P.S. Synthesis, growth and characterization of a new NLO active chalcone derivative - 4-chloro-N-\{3-[(2E)-3-(methoxyphenyl)prop-2Enoyl]phenyl\}benzamide monohydrate. Journal of Molecular Structure 2019, 1176, 838-846, https://doi.org/10.1016/j.molstruc.2018.09.021.

88. Kumara, K.; Dileep Kumar, A.; Naveen, S.; Ajay Kumar, K.; Lokanath, N.K. Synthesis, spectral characterization and X-ray crystal structure studies of 3-(benzo[d][1,3]dioxol-5-yl)-5-(3-methylthiophen-2yl)-4,5-dihydro-1H-pyrazole-1-carboxamide: Hirshfeld surface, DFT and thermal analysis. Journal of Molecular Structure 2018, 1161, 285-298, https://doi.org/10.1016/j.molstruc.2018.02.068.

89. Kumara, K.; Dileep Kumar, A.; Ajay Kumar, K.; Lokanath, N.K. Synthesis, spectral and X-ray crystal structure of 3-(3-methoxyphenyl)-5-(3-methylthiophen-2-yl)-4,5-dihydro-1H-pyrazole-1-carboxamide: Hirshfeld surface, DFT calculations and thermo-optical studies. Chemical Data Collections 2018, 13-14, 4059, https://doi.org/10.1016/j.cdc.2018.01.001.

90. Messaoudi, I.; Aribi, I.; Zouhour, Z.; Ayachi, S.; Othman, M.; Said, A.H. Electrosynthesis and characterization of a new semi-conducting oligomer deriving from a disubstituted chalcone: 4-dimethylamino -4'-methoxychalcone. Journal of Molecular Structure 2020, 1231, 129810 , https://doi.org/10.1016/j.molstruc.2020.129810.

91. Chen, H.; Fang, S.; Wang, L.; Li, X.; Yan, J.; Zhang, N.; Zheng, K. Tetraphenylene-chalcone hybrid derivatives: Synthesis, structural, fluorescence properties and imaging in living cells, Journal of Molecular Liquids 2021, 321, 114913, https://doi.org/10.1016/j.molliq.2020.114913.

92. Patil, P.S.; Gummagol, N.B.; Ekbote, A.; Wong, Q.A.; Quah, C.K.; Shkir, M.; Maidur, S.R.; Rao, S.V. Structural and femtosecond third-order non-linear optical properties of electron donor-acceptor substituted chalcones: An experimental and computational approach. Journal of Molecular Structure 2020, 1219. 128523, https://doi.org/10.1016/j.molstruc.2020.128523 